\title{
Længsel efter positiv frihed
}

\section{Sociale utopier i Kafkas kortprosatekst "Udflugten til bjergene"}

\author{
Løft Jeres blik mod bjergene, \\ hvorfra hjælpen kommer til Jer! \\ (Augustinus, Bekendelser)
}

I.

Færdedes man i midten af 1990'erne i det boblende og mangfoldige berlinske litteraturmiljø, kunne man risikere at blive konfronteret med tekster af Franz Kafka; især med en bestemt kortprosatekst, der i disse år dannede rammen omkring en gruppe unge litterater i den berlinske undergrund: gruppen Lauter Niemand. Gruppens navn var utvivlsomt hentet fra Kafkas kortprosatekst "Udflugten til bjergene", og det blev kotyme, at præcis denne kortprosatekst fra 1910 blev læst op inden gruppens egne litterære arrangementer. Hvorvidt denne praksis var præget af de forskningsmæssige resultater omkring kortprosateksten, vides ikke. Men der hersker ingen tvivl om, at "Udflugten til bjergene" spiller en central rolle inden for den omfattende forskningslitteratur om Kafkas værker. Udgangspunktet for denne centrale rolle var især et essay, som den tyske Kafkaforsker Hans Thies Lehmann publicerede i 1984 under titlen "Der buchstäbliche Körper. Zur Selbstinszenierung der Literatur bei Franz Kafka". I essayet fremlægger Lehmann en ny tolkning af Kafkas berømte - og ved første øjekast ret mystiske - kortprosatekst, der skabte en del opsigt ved sin tilbliven og sidenhen er blevet refereret gang på gang. Der kan nemlig ikke herske tvivl om, at vi, som Lehmann udtrykker det, i teksten har at gøre med en "allegori over bogstaverne" (Lehmann 1984, 216). De mange "ingen", som dukker op i teksten, henviser ifølge denne tolkning til de små bogstaver på papiret, der hver især ikke har nogen betydning, men først i deres interne sammenspil danner en form for sammenhængende mening. Teksten handler derfor ifølge Lehmann ikke om ydre begivenheder eller en ydre virkelighed, men sigter efter at unddrage sig et 
forhold til den ydre verden. I stedet for at fremskrive en eller anden form for betydning iscenesætter denne tekst ifølge Lehmann "sin egen realitet af unddragelse, ikke-viden, ikke-præsens" (ibid. 216). Bogstaverne og skriften anvancerer således til "en intensiv egenrealitet" (ibid. 217), hvis sproglige dynamik har gjort sig fri af alle relationer til den ydre omverden: "På den ene side bliver det konkrete reduceret til et absolut minimum, på den anden side udfolder teksten sig som af-skrift, idet den forholder sig til dette minimum som afdragende skrift. Ved signifikansens (tendentielle) nulpunkt produceres imidlertid en ny rigdom af indvævninger" (ibid. 217). Og Lehmann bliver i sit essay ikke stående ved dette. Læsningen af Kafkas kortprosatekst som en allegori over bogstaverne er nemlig kun et eksempel på den generelle tendens i Kafkas værker til at nedvurdere den ydre virkelighed, der i stigende grad erstattes med en rent sproglig selvreferentialitet. Som det udtrykkes:

64 Kafkas tekster søger at unddrage sig referensen, det re-præsenterende forhold til den ikke-sproglige realitet. Man kunne vove den tese, at den ofte fremhævede "renhed", som Kafka er på jagt efter i sin skrift, og som fik ham til at fortvivle over alle metaforer, ikke betød andet end den i sig selv kredsende sprogbevægelse, som er blevet helt og aldeles til musik, renset for enhver betydning (ibid. 218).

I de følgende år er denne tese blevet refereret gang på gang i forskningslitteraturen, hvor en hel forskningstradition læser Kafkas værker ud fra dette perspektiv. Og med henblik på Kafkas kortprosatekst fra 1910 har man set et hav af forskellige tolkninger, der allesammen ligger i forlængelse af Lehmanns allegoriske tolkning af teksten (se f.eks. Jagow 2008; Strowick 2004; Kurz 1994). I dag, næsten tredive år efter Lehmanns essay blev publiceret for første gang, må man imidlertid stille spørgsmålet, om Kafkas kortprosatekst ikke også indeholder andre tolkningsmuligheder, der peger ud over den siden 1980'erne udbredte måde at læse teksten på. Ser man nærmere på tekstens indre opbygning, får man nemlig indtryk af, at den ikke blot kan læses som en "allegorisk personfikation af skriftens bogstaver" (Kurz 1994, 62), men at den i mindst lige så høj grad handler om forskellige former for sociale interaktioner. Disse interaktioner stilles i teksten over for hinanden og vurderes i deres forhold til fortælleren. Set fra dette perspektiv åbner der sig derfor et nyt tolkningsperspektiv, der peger ud over den hidtil mest udbredte læsning af teksten. Kafkas kortprosatekst "Udflugten til bjergene" viser, set fra dette perspektiv, fortællerens længsel efter et utopisk fællesskab, hvor den individuelle frihed ikke undertrykkes, men derimod understøttes og bekræftes af de sociale interaktionspartnere. I bund og grund har vi således at gøre med individets søgen efter anerkendelse, der skal overvinde både den "mest skrækkelige ensomhed" (Kafka 1967, 402), der hos Kafka gang på gang beskrives som isolation og negativ frihed, og det klaustrofobiske "fællesskab", der forhindrer individets frihed og derfor for det meste opleves som undertrykkende. Anerkendelsesutopien danner her en potentiel udvej, en modreaktion, hvor de to dystopier, som store dele af forfatterskabet ellers handler om, bliver erstattet af en ny og anden form for social interaktion; hvor ensomheden erstattes med den positive frihed inden for en velfungerende social sammenhæng. 


\section{Fraværet af den positive frihed}

"Udflugten til bjergene" blev oprindeligt til i forbindelse med omskrivningen af prosateksten "Beskrivelse af en kamp" i 1910. Kafka havde på dette tidspunkt allerede forfattet en første version af teksten, men begyndte nu at arbejde på en anden version, hvori der også for første gang indgik et afsnit om en "udflugt til bjergene", der på besynderligste vis handlede om et selskab af "lutter ingen" (Kafka 2008b, 47). I modsætning til "Beskrivelse af en kamp", der forblev fragmentarisk og først er blevet publiceret adskillige år efter Kafkas død, fik "Udflugten til bjergene" allerede et liv i 1912. I sommeren dette år fik Kafka - ved hjælp af Max Brod, der præsenterede forfatteren for den unge og opadstræbende forlægger Kurt Wolff i Leipzig - mulighed for at publicere sin første bog, et foretagende, som imidlertid viste sig at være ganske vanskeligt, idet Kafka på dette tidspunkt ikke rådede over et sammenhængende manuskript, som kunne tilbydes forlaget. Han besluttede sig derfor til at samle i alt 18 kortprosastykker, der allerede delvist havde været publiceret i tidsskrifter eller - som "Udflugten til bjergene" - stammede fra en helt anden kontekst, og udgav dem sammen under overskriften Betragtning. Kafkas forhold til denne første bogudgivelse - disse "lyspunkter i en uendelig forvirring" (Kafka 1967, 218), som han engang kaldte dem - forblev derfor også ambivalent gennem det meste af hans liv. For ham selv skete gennembruddet som forfatter først med nedskrivningen af "Dommen" i september 1912, kort efter hans første møde med Felice Bauer, som han dedikerede fortællingen til. "Udflugten til bjergene" åbner imidlertid, som vi vil se, allerede for nogle af grundkonflikterne i forfatterskabet. I al sin korthed og skønhed lyder teksten:

46 "Jeg ved ikke", råbte jeg uden klang, "jeg ved det jo ikke. Hvis ingen kommer, så kommer der bare ingen. Ingen har jeg gjort noget ondt, ingen har gjort mig noget ondt, men ingen vil hjælpe mig. Lutter ingen. Men sådan er det dog ikke. Det er bare at ingen hjælper mig - ellers vil lutter ingen være kønt. Jeg kunne godt tænke mig - hvorfor ikke - at tage på en udflugt med et selskab af lutter Ingen. Op i bjergene selvfølgelig, hvorhen ellers? Hvor disse Ingen dog maser sig sammen, disse mange arme der strækker sig ud eller hægter sig sammen, disse mange fødder, adskilt af bittesmå skridt! Det forstår sig at alle er i kjole og hvidt. Vi går sådan lala, vinden blæser gennem de mellemrum som vi og vores lemmer danner. Halsene bliver fri i bjergene! Det er et under at vi ikke synger." (Kafka 2008a, 18)

Teksten hører uden tvivl til blandt de mere udfordrende tekster, der kendes fra Kafkas tidlige værker. Især ophobning af lutter "ingen", der gentages i forskellige varianter, virker umiddelbart mærkværdig, og også selskabets "udflugt til bjergene", hvor medlemmernes halse "bliver fri" og de næsten bryder ud i sang, forbliver ved første læsning uigennemskuelig. Desuden forbliver fortællerens nærmest paradoksale bemærkning om, at hele udsagnet, som teksten refererer, "råbtes uden klang", ejendommelig. For kan man egentlig råbe uden klang? Hvilken handling kan der være tale om, hvor der både råbes og ikke kommer nogen lyd? I forskningslitteraturen har man læst denne bemærkning som en negation af fortællerens eget udsagn, eller snarere: som en negation af udsagnets fonetiske karakter. Der henvises med denne bemærkning derfor ifølge Lehmann til skriften. Fordi "lydløst sprog", ifølge 


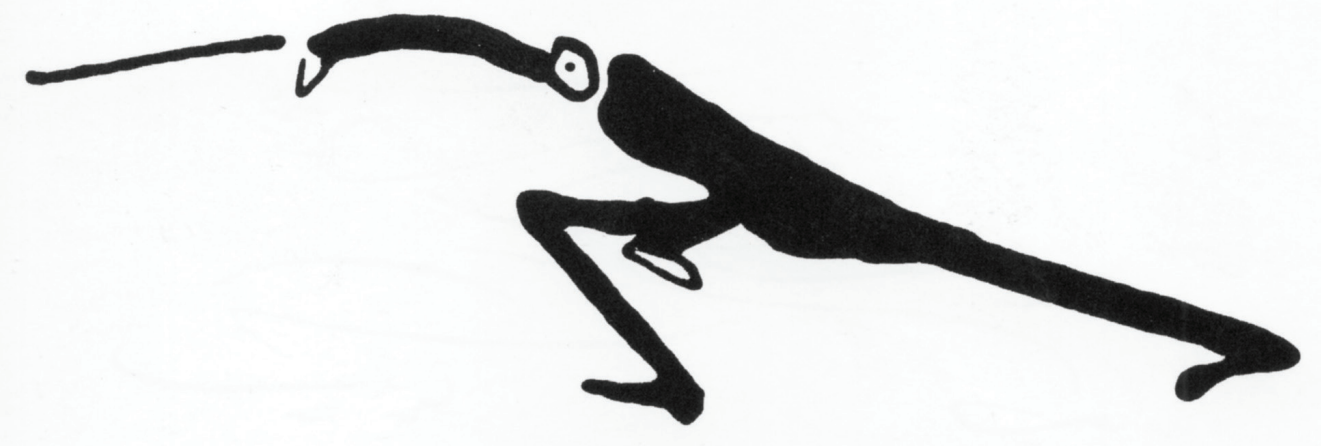

ham, "dog er skriften" (Lehmann 1984, 216). Og andre som fx Strowick ser på en lignende måde en fornægtelse af tekstens egen opbygning, en negation af dens udsigelsesposition (Strowick 2004, 573f.).

Ser man i første omgang bort fra fortællerens bemærkning om sit eget udsagn og ser på indholdet af selve det udsagn, vi får refereret af fortælleren, får vi imidlertid et andet indtryk af tekstens mest centrale konflikter. Rent formelt er det i denne forbindelse påfaldende, at teksten falder i to dele: En første del, der er holdt i indikativ, og en anden del, der indledes af en konjunktivkonstruktion ("Jeg kunne godt tænke mig...”). Det ser ud, som om begge dele er tematisk forbundet med hinanden: Selve "udflugten til bjergene", som fortælleren på et tidspunkt ret overraskende introducerer, kan læses som en modreaktion på tilstandsbeskrivelsen, som fortællerens udsagn umiddelbart begynder med: På introduktionen af den faktisk eksisterende tilstand følger med andre ord ønskefantasien, "en passus i mulighedsformen" (Lehmann 1984, 216). Denne indre sammenhæng bliver mere tydelig, når man kigger nærmere på tilstandsbeskrivelsen i første del af fortællerens udsagn, der går forud for udflugten til bjergene. I denne del har vi nemlig at gøre med en beskrivelse af forskellige former for sociale interaktioner, der stilles ved siden af hinanden og efterfølgende vurderes ud fra deres værdi for fortælleren. Det bliver særlig tydeligt i udsagnets centrale tredje sætning. Men allerede inden gives der en første introduktion til situationen, som fortælleren befinder sig i: Fortælleren er, erfarer vi, i en situation af tvivl, han forholder sig overvejende og spørger tilsyneladende om situationens baggrund ("Jeg ved det ikke"). Samtidig står fortælleren åbenbart alene og venter forgæves på, at nogen skal komme til ham ("Hvis ingen kommer, så kommer der bare ingen"). Situationen bliver imidlertid først for alvor reflekteret i næste sætning, hvor vi hører om tre forskellige "ingen", der hver især synes at pege på bestemte former for sociale interaktioner. Som det hedder i tredje sætning: "Ingen har jeg gjort noget ondt, ingen har gjort mig noget ondt, men ingen vil hjælpe mig". Denne sætning giver en første forklaring på udgangspunktet, på fortællerens overvejelser, og det er også disse tre "ingen", der i næste sætning bliver sammenfattet til det for teksten centrale paradigme om "lutter ingen". Vigtigt er imidlertid i første omgang: Hvad er det for sociale interaktioner, vi her har at gøre med? Det er påfaldende, at 
de første to interaktionsformer - de første to "ingen", så at sige - i deres substans og karakter er identiske: I begge tilfælde er der tale om handlinger, der forbindes med det idiomatiske udtryk at gøre noget "ondt" mod nogen. Forskellen ligger udelukkende i spørgsmålet om, hvem der er den aktive part, altså handlingens agens, og hvem der er passiv, handlingens modtager - kvalitativt set er der ingen forskel, fra dette perspektiv har vi at gøre med identiske handlinger. Og det er selvfølgelig påfaldende, at det er det samme idomatiske udtryk, som Kafka nogle år senere bruger i den berømte første sætning af Processen, hvor vi får at vide, at Josef K. netop er blevet arresteret, uden at han "vidste af at have gjort noget ondt" (Kafka 1991, 7). Vigtigere er imidlertid dette idiomatiske udtryks indhold. Historisk set stammer udtrykket om at gøre noget ondt formentligt fra übelthat, missethat, altså fra en ond handling, der skader den anden eller har til hensigt at skade den anden. At gøre nogen "ondt" er derfor ikke begrænset til hverken fysiske eller psykiske dimensioner: Det kan handle om overgreb mod den anden interaktionspartners kropslige integritet, eller den skadelige påvirkning af den andens psykiske konstitution, ligesom der - især historisk set - kan være tale om ondsindede intentioner. Jeg vil derfor foreslå at tolke dette udsagn som en henvisning til en form for social interaktion, der skader eller har til formål at skade den anden. Dette betyder samtidig også, at en sådan interaktionsform omfatter en principiel indskrænkning af den andens frihed: Der er tale om en begrænsning, en indskrænkelse eller indsnævring af den andens frihed, og - som konsekvens heraf - dennes handlingsmulighed, fordi enhver form for ond handling mod en anden nødvendigvis må medføre en indskrækning af denne andens handlingsrum. Med henblik på Kafkas kortprosatekst er det imidlertid afgørende, at denne begrænsende og indskrænkende form for social interaktion ikke er til stede. Den glimrer snarere ved sit fravær. Fortællerens situation er med andre ord kendetegnet ved, at der ikke foreligger skadelige påvirkninger, hverken fra fortælleren selv mod andre eller fra andre mod fortælleren. Vi får derfor indtryk af et subjekt, der kan udfolde sig uden at nogen begrænser det, eller at det begrænser nogen.

Den ultimative form for en sådan gensidig, ubegrænset og skadeløs frihed er selvfølgelig ensomheden. Tekstens udgangspunkt, efter hvilket fortælleren åbenbart uforløst venter på, at nogen skal komme, peger præcis i denne retning. Og også den tredje "ingen", som introduceres lige efter de to allerede omtalte "ingen", bekræfter denne læsning: Åbenbart er der ingen, erfarer vi nu, der vil "hjælpe mig". Fortælleren ser ud til at være alene, han venter tilsyneladende på nogen, der dog ikke kommer til undsætning. Den tredje "ingen" ligger altså i umiddelbar forlængelse af de første to. Men samtidig tilføjes en ny dimension. Handlede de to første "ingen" om fraværet af gensidige begrænsninger, er der nu tale om fraværet af en støttende og hjælpende indsats fra andre. Den tredje ingen er med andre ord væsensforskellig fra de første to: Handlede de om skadelige påvirkninger af hinanden, er der nu tale om støttende og bekræftende former for social adfærd, der ikke begrænser, men udvider og forøger subjektets handlingsmuligheder.

Hvad angår forskningslitteraturen om Kafkas kortprosatekst, er allerede disse overvejelser værd at hæfte sig ved - her har man nemlig gentagne gange hævdet, at de forskellige "ingen" i Kafkas tekst er kendetegnet ved ikke at have nogen substans: 
at der er tale om "en sammenkædning af hele eller partielle negationer" (Lehmann 1984, 216), som Lehmann mener, eller at de, som Strowick påstår, iscenesætter navnets og betydningens "udstregning" (Strowick 2004, 571). Disse antagelser er dog tydeligvis forhastede. Som vi har set, foreligger der snarere tydeligt afgrænsede betydningsdimensioner, der alle henviser til bestemte former for sociale interaktioner. Set fra et socialfilosofisk perspektiv kan man sågar tale om forskellige frihedsbegreber, der her stilles over for hinanden. Således har de to første "ingen" nemlig en tydelig nærhed til konceptet negativ frihed, der siden Isaiah Berlins berømte teser netop er defineret ved fraværet af $y$ dre forhindringer. Fraværet af skadelige og begrænsende påvirkninger i de to første "ingen" peger altså, hvis man læser det fra dette perspektiv, på eksistensen af ubegrænsede udfoldelsesmuligheder (se bl.a. Honneth 2000, 318). Dette er imidlertid, som vi ser i kortprosatekstens tredje sætning, ikke blevet udvidet med en forestilling om positiv frihed. Den positive frihed er siden Berlin defineret som en frihed til noget; en frihed, der ifølge de fleste nyere teoretikere på området først kan opbygges ved en støttende og hjælpende tilgang fra andre interaktionspartnere (se f.eks. Honneth 2006, 222ff; Taylor 1988, 114ff).

Som helhed giver de første sætninger dermed indtryk af en situation, der er kendetegnet ved, at fortælleren hverken er udsat for begrænsende eller støttende interaktioner. Han kan tilsyneladende udfolde sig helt, som han vil: Hans frihed bliver ikke indskrænket, og han selv indskrænker heller ingen andens frihed. Samtidig findes der ingen støttende og hjælpende opbakning til ham. Det ser ud, som om fortælleren vitterligt står alene og råber ud i verden, i en - åbenbart forgæves - forhåbning om, at nogen vil komme til ham.

\section{Udflugten som modutopi}

Teksten forbliver imidlertid ikke stående dér. Fortælleren nøjes nemlig ikke med at opremse disse tre "ingen", men begynder efterfølgende at vurdere dem i forhold til hinanden. Således sammenfattes de tre "ingen" først under det centrale udsagn "lutter ingen", inden de kort efter bliver valoriseret: "Men sådan er det dog ikke", tilkendegiver fortælleren, inden han siger den centrale sætning: "Det er bare at ingen hjælper mig - ellers vil lutter ingen være kønt" [fremhævning MS]. Udsagnets pointe er ikke til at tage fejl af: 'Lutter ingen' ville være dejligt, hvis blot den tredje ingen "ingen hjælper mig" - ikke var til stede. Vi har altså at gøre med en negation af negationen, der dog ikke ender i en ren negativitet, men efter traditonel matematisk logik åbner for en positiv værdi. Negationen af den positive friheds fravær fører nemlig til den modsatte situation: til tilstedeværelsen af positiv frihed. For at sige det på en anden måde: Efter introduktionen af de tre ingen bliver én af dem, den tredje, negeret. Fraværet af den positive frihed - synes udsagnet at være - er problematisk, ellers ville situationen være fin. Dermed peges direkte mod en positiv idealtilstand, hvor den negative frihed idealtypisk skal forbindes med positiv frihed. Fortællerens udgangssituation er altså ret klar: Der lægges op til, at den negative frihed, hvor ingen skader og begrænser hinanden, anses som noget skønt og ønskværdigt, men der peges samtidig på, at den udelukkende negative frihed burde udvides med den positive frihed, der består i en støttende og opbakkende social adfærd. 
Vi vil senere se, at denne utopi om en positiv frihed også fremskrives en del andre steder i Kafkas forfatterskab, og i sidste konsekvens endda danner det egentlige formål i Kafkas utopiske tænkning. Med blik på kortprosateksten fra 1910 er det imidlertid især påfaldende, at vi præcis nu, efter denne komprimerede beskrivelse af en mangelfuld tilstand, ser overgangen til ønskefantasien, der består i fortællerens drøm om en udflugt til bjergene. Udflugten tildeles med andre ord funktionen som et modsvar til den mangelfulde tilstand, som fortælleren først introducerede. Lige efter henvisningen til, at "lutter ingen" ville være "kønt", hvis blot den tredje ingen ikke var til stede, hedder det således: "Jeg kunne godt tænke mig - hvorfor ikke - at tage på en udflugt med et selskab af lutter Ingen." Og i næste sætning bliver udflugtens mål konkretiseret: "Op i bjergene selvfølgelig, hvorhen ellers?". I forskningslitteraturen har især ændringen af retskrivningen - nu skrives "lutter Ingen" pludselig med stort - skabt en del forvirring. I forlængelse af den udbredte allegoriske tolkning af teksten har man også tolket dette som et signal om skriftens selvreferentialitet. Overgangen fra "lutter ingen" til "lutter Ingen" læses her som en henvisning til skriftens materialitet, eller til den for al skrift konstituerende differens mellem tegnene (Kurz 1994, 62). Og i umiddelbar forlængelse af Jacques Derridas overvejelser om Maurice Blanchot diagnosticerer Strowick i Kafkas tekst "en differens, der ikke kan høres, men udelukkende læses" (Strowick 2004, 579). Teksten iscenesætter på denne måde ifølge hende sprogets differentialitet og dets uafsluttethed. Ifølge Strowick har vi derfor at gøre med en moderne odyssé, "som ikke gennemfører en tilbagekomst til udgangspunktet", og som i sidste konsekvens også bliver til "læsningens odyssé": Enhver hjemkomst til "betydningen" bliver i teksten forhindret (ibid.).

I forlængelse af den her fremlagte tolkning af den første del af teksten åbner sig imidlertid også en anden læsning, der er mere tematisk orienteret. Ifølge denne tilgang kan overgangen fra "lutter ingen" til "lutter Ingen" også læses som et signal om en ny sammensætning af denne gruppe af "ingen": Mens den første gruppe endnu bestod af både tilstedeværelsen af negativ frihed og fraværet af positiv frihed, er den utopiske tilstand, der nu introduceres, jo netop præget af fraværet af den tredje "ingen", altså af tilstedeværelsen af positiv frihed. Den første henvisning til "lutter ingen" i teksten er altså også tematisk adskilt fra den senere henvisning til "lutter Ingen". I stedet for at være intet andet end et signal om sprogets formale dimension, åbner der sig med andre ord en indholdsmæssig tolkningsmulighed. En tolkning, som også styrkes af det faktum, at Kafka først i den nye version i 1912 har tilføjet denne ændring i stavemåden - i den første version af "Beskrivelse af en kamp" var denne endnu ikke til stede (se Kafka 1993, 141f.). Især bliver det på denne måde tydeligt, at udflugten til bjergene - som netop ikke skal foregå med en gruppe af "lutter ingen", men med den nye gruppe af "lutter Ingen" - skal læses som et modsvar, et modideal til de mangler, som "lutter ingen" endnu var præget af. Og dermed åbner sig også en ny forståelse af udflugten til bjergene og selskabet, som fortælleren efter eget udsagn ønsker at foretage denne udflugt med: I umiddelbar forlængelse af tilstandsbeskrivelsen sigtes der nu efter en tilstand, hvor ingen skader og begrænser hinanden, men hvor de involverede personer hjælper hinanden. Den udelukkende negative frihed skal udvides med den positive frihed. En del konkrete dimensioner 
i Kafkas beskrivelse af udflugten bekræfter denne læsning: Således er det for eksempel påfaldende, at Kafka ikke benytter sig af ordet "fællesskab", som ellers ville have været oplagt, men bruger det mindre tunge ord "selskab". Allerede dermed signaleres, at der ikke er tale om et klaustrofobisk tæt samvær, et Gemeinschaft, der ikke giver plads til individuel afvigelse, men snarere en mere løst knyttet, en mere åben form for socialt samvær, et Gesellschaft. Og selve beskrivelsen af disse "lutter Ingen" og deres indbyrdes forhold til hinanden under udflugten peger i en lignende retning. Således signaleres der på den ene side, at disse Ingen "maser sig sammen", at de "hægter sig sammen", at de altså udgør en form for samvær, mens der på den anden side gives udtryk for, at de "strækker sig ud", er "adskilt" fra hinanden, og har "mellemrum" mellem deres lemmer, gennem hvilke vinden - det klassiske symbol på friheden - blæser. Beskrivelsen af deres indbyrdes forhold er derfor ambivalent: Teksten signalerer både en frihed og åbenhed over for hinanden og et samvær, en overvindelse af ensomheden, i og med der hele tiden knyttes bånd, skabes forbindelse, på udflugten til et fælles mål. Udflugten til bjergene er med andre ord kendetegnet ved den nærmest paradoksale sammenskrivning af fællesskabet ('mase sig sammen') med den individuelle frihed ('mellemrum'). Med henblik på tilstandsbeskrivelsen i den første del af teksten, der ligger forud for ønskefantasien, kan man sige, at der i udflugten bibeholdes de første to "ingen" - at ingen skader og begrænser hinanden - mens ensomheden og afsondretheden samtidig overvindes at ingen hjælper. Dermed vil præcis det problem være overvundet, som fortælleren i tilstandsbeskrivelsen ellers har fremhævet som grundproblem: Fraværet af positiv frihed. Udflugten til bjergene er åbenbart en modreaktion, en urealistisk drømmefantasi om det perfekte fællesskab, hvor alle hjælper hinanden, og ingen undertrykker og begrænser hinanden.

Udflugtens fysiske mål - bjergene - synes at være det oplagte sted for et sådant utopisk fællesskab. Det er her, at luften bliver fri, at individet helt og aldedes kan udfolde sig, og at man - således tolkes motivet siden Francesco Petrarcas berømte bestigning af Mount Ventoux i 1336 - nærmer sig naturens og himlens indre orden. Og det er muligvis ikke tilfældigt, at en del af motiverne i Kafkas kortprosatekst vækker minder om Petrarcas berømte brev til vennen Francesco Dionigi, hvor han beretter om opstigningen til Mount Ventoux, deriblandt ikke mindst det for Petrarca centrale motiv om vinden og det i hans brev ligeledes omdiskuterede spørgsmål om sammensætningen af det selskab, der skal følge ham til bjergets top (se Petrarca 1957). Udvider man det med den hos Jean Jacques Rousseau og i den tyske romantik udbredte forbindelse mellem bjergmotivet og friheden, og med Friedrich Nietzsches gentagne referencer til opstigning til bjergene som en tilnærmelse til sandheden, vil man sikkert kunne kortlægge motivets historiske betydning yderligere (se f.eks. Nietzsche 1966 I, 861). For den her diskuterede sammenhæng er det imidlertid især relevant at udflugten ender i en forsigtig eufori, der dog ikke helt forløses: Når udflugtens deltagere trækker i festtøj og samtidig er tæt på at bryde ud i sang, virker det lettere ironisk, samtidig med at det understreger udflugtens højtflyvende og dybt seriøse formål. Det virker, som om fortælleren selv i sin ønskefantasi ikke helt tør give sig hen til utopiens fulde udfoldelse og blot antyder muligheden for sang og frihed. Samtidig er udflugtens mål, dens telos, tydeligt genkendeligt. Når Bettina von Jagow i 2008 
skriver, at udflugten til bjergene afspejler "jegets flugt fra samfundet" (Jagow 2008, 408), synes dette ikke at svare til tekstens egen opbygning: Udflugten introduceres som en reaktion på den mangelfulde tilstand, hvor fortælleren står alene og forgæves venter på, at nogen skal hjælpe ham. Imod dette udgangspunkt har vi at gøre med en frihedsbevægelse, der netop ikke foretages alene, men i fællesskab: I et selskab, hvor ingen begrænser hinanden, og alle hjælper hinanden.

\section{Anerkendelsesutopier}

Man vil længe kunne diskutere andre forlæg, ved siden af Petrarca, Rousseau og Nietzsche, der muligvis bevidst eller ubevidst har påvirket valget af motiverne i Kafkas tekst. Og en del andre motiver i Kafkas kortprosatekst ville kunne diskuteres nærmere. Afgørende for forskningslitteraturen er imidlertid, at vi her ser en åbning for en helt ny tilgang til Kafkas værker, der ikke peger på religiøse, psykoloanalytiske eller marxistiske tolkinger - for slet ikke at tale om de tekstimmanente og dekonstruktivistiske læsninger - men derimod sætter de sociale interaktioner og intersubjektive konfliktkonstellationer i centrum for analysen. Man vil her nærmest kunne tale om et paradigmeskift i forskningslitteraturen, om en social vending. Også et sådant paradigmeskift vil imidlertid kunne knytte an til dele af den eksisterende forskningslitteratur. Således har man flere gange diagnosticeret en "grundkonflikt" i Kafkas forfatterskab, der ifølge Thomas Anz skulle bestå i en modsætning mellem "individet og almenheden". Denne modsætning er de fleste forskere ifølge Anz enige om, de har blot tolket modsætningen i forskellige retninger. Således har man tolket den "marxistisk som kamp mellem fremmedgjort og ikke-fremmedgjort arbejde, eksistentialistisk som modsætning mellem egentlig og uegentlig tilstedeværelse, religiøst som forskel mellem helligt og profant, psykoanalytisk som kamp mellem det og over-jeg'et, kulturkritisk som kontrast mellem natur og civlisation eller på det seneste poststrukturalistisk som differens mellem krop og skrift eller antiødipal begær og ødipal underkastelse" (Anz 1989, 90). Det er samtidig kendetegnende for næsten alle disse forskellige tolkninger af grundkonflikten, at modsætningen mellem individualitet og almenhed for det meste læses som statisk, som uovervindelig. Meget tydeligt bliver det eksempelvis i et af de tidlige bidrag til Kafkaforskningen, nemlig i Jürgen Kobs strukturalistiske analyse af forfatterskabet. Kobs afslutter sin omfattende studie med en læsning af Kafkas kortprosatekst "Træerne", som ifølge ham netop peger på modsætningsforholdet mellem frihed og fællesskab. Begge dele falder hos Kafka ifølge Kobs gang på gang i sine ekstremer, der gensidigt ekskluderer hinanden, uden at en tilnærmelse mellem polerne er mulig. Fællesskabet er nemlig ifølge Kobs altid tæt forbundet med fangenskab - al den stund fællesskabet ifølge denne læsning består i en "altomsluttende afhængighed", der udelukker den individuelle frihed (Kobs 1970, 529). Samtidig kan flugten fra fællesskabet, nemlig koncentrationen af den individuelle frihed, ifølge Kobs "ikke opfattes som noget positivt, så længe den er korreleret med den totale isolation”. Frihed og fællesskab synes at udelukke hinanden. Udvejen skulle derfor bestå i et fællesskab, der overvinder isolationen uden at indskrænke friheden. Ifølge Kobs er dette imidlertid ikke muligt hos Kafka: 
6 Isolationen derimod - vi kan beskrive den som det 'individuelle's negative variant - ville alene kunne overvindes ved hjælp af det menneskelige fællesskab. Men alle sociale ordener er underlagt [...] den altomsluttende afhængighed, det "fælles" negative variant (ibid.).

Kafkas kortprosatekst fra 1910 synes at placere sig i dette spændingsfelt mellem frihed og afhængighed. Et spændingsfelt, som vi også finder i mange af Kafkas senere værker. Eksempelvis beskriver flere af de mest berømte fortællinger netop undertrykkelsen af den individuelle frihed i de sociale interaktioner, om det så er i forhold til familiestrukturen, som i "Dommen" eller "Forvandlingen", eller med blik på de store historiske udviklinger i eksempelvis En rapport til et akademi, der tydeligvis er påvirket af Nietzsches Moralens genealogi. Samtidig ser vi gang på gang individets flugtfantasier, dets søgen efter en ubegrænset ensomhed hinsides det sociale fællesskab, ligesom i de tidlige prosastykker om "Den lille ruinbeboer". Det er imidlertid påfaldende, at disse flugtfantasier aldrig er succesfulde, men ender i ensomhed og isolation. Begge dimensioner synes altså, præcis som Kobs skriver, gang på gang at udelukke hinanden. Nærmest paradigmatisk ses dette i de to sidste store romanfragmenter, Processen og Slottet. Mens vi i Processen har at gøre med omverdenens pres mod den enkelte, der forfølges, arresteres og til sidst slås ihjel, er Slottet præget af det modsadrettede udgangspunkt: Her har vi at gøre med en ensom rejsende, der ankommer til lokalsamfundet og drømmer om at blive del i det omgivende fællesskab. De ydre betingelser afspejler disse forskellige udgangspunkter: Mens Josef K. i Processen til stadighed - og især i nærheden af domstolene - konfronteres med en undertrykkende, klaustrofobisk varme, som medfører åndenød og som er skyld i, at Josef K. på et tidspunkt under sit ophold på domstolenes kontorer besvimer (se Kafka 1991, 76ff.), står K. i Slottet gentagne gange uden for fællesskabet i sneen og ser med længsel gennem vinduerne ind i de lokale bønders stuer, der er opvarmet ved dejlig pejseild. Begge ekstremer er altså kendetegnet ved deres længsel efter det modsatte: Josef K. drømmer om "et frisk luftpust” (Kafka 1991, 80), om koldere luft, hvor der kan åndes frit, og K. drømmer om den varme, som fællesskabet synes at udstråle. Idealet synes derfor også at ligge midt i mellem: i et fælleskab, der giver beskyttende varme mod ensomhedens kulde og samtidig tillader den enkelte frihed nok til at kunne ånde frit. "Udflugten til bjergene" afspejler denne konfliktsituation: I fortællerens ønskefantasi skal begge dimensioner - fællesskab og frihed - kombineres: Dér bliver halsene frie, luften er tilgængelig, samtidig med at fortælleren, i det mindste inden for ønskefantasien, er sammen med andre interaktionspartnere, der hverken skader eller begrænser, men hjælper ham. Når Kobs antager, at der ikke findes noget mellemsted mellem isolation og fangenskab, er det muligvis rigtigt med hensyn til den hårde realitet, Kafkas helte færdes i: Men han overser, hvordan præcis dette mellemsted gang på gang fremstår som det egentlige formål, det utopiske mål, som Kafkas helte stræber efter.

Især i Kafkas senere forfatterskab fremstår dette utopiske mellemsted som en søgen efter anerkendelse. Eksempelvis hører vi i de sene kunstnerfortællinger gang på gang, hvordan kunstneren defineres som en outsider i forhold til fællesskabets normer og ritualer, samtidig med at kunstneren prøver at blive anerkendt på grund 
af denne særegenhed og afvigelse. Således består Josefines kunst i "Sangerinden Josefine eller Musefolket" ikke nødvendigvis i at synge, men i at adskille sig fra fællesskabet - en adskillelse, som samtidig kombineres med en vedvarende "kamp for sin anerkendelse" (Kafka 2008a, 230). Og sultekunstneren i Kafkas fortælling med samme navn er på en lignende måde optaget af at skille sig ud fra mængden, samtidig med at også han benytter denne søgen efter afvigelse som en stræben efter anerkendelse: Således er det netop afvigelsen fra fællesskabet, der skal danne baggrunden for publikummets "beundring for ham" (Kafka 2008b, 212; se også Schramm 2006, 191f.). I den nye forskning har man her med rette talt om outsideren som motiv i Kafkas værker (Neumann 2011). "Udflugten til bjergene" viser samtidig, at heltene i Kafkas forfatterskab netop ikke stiller sig tilfredse med afvigelse og singularitet, men derimod søger et socialt samvær, hvor den enkelte er anerkendt i kraft af sin anderledeshed.

I Kafkas eget liv finder vi blandt andet disse længsler i hans forestilling om et religiøst fællesskab, hvor den enkelte - idealtypisk - ville have mulighed for uforstyrret at udfylde den specifikke plads, som tilkommer vedkommende i fællesskabet (se bl.a. Robertson 1988, 30ff.). I dagligdagen ser vi især denne længsel i kærligheden. I modsætning til den eksisterende forskning på området, der for det meste læser Kafkas egne ægteskabsplaner ud fra modsætningen mellem borgeren og kunstneren (se fx Kurz 1980, 4), er det nemlig tydeligt, at Kafka også her fremskriver og sigter efter et utopisk fællesskab, hvor alle hans individuelle særegenheder og ejendommeligheder skal kunne accepteres og anerkendes i et socialt fællesskab. Således skelner Kafka for eksempel i et brev til Felice Bauer fra den 16. Juni 1913 mellem to former for socialt samvær, det "nødvendige" og det "ikkenødvendige" (Kafka 1967, 401) samvær. Det nødvendige samvær består ifølge ham i kærligheden, som han definerer som en "menneskelig overensstemmelse", altså en overensstemmelse, som eksisterer "langt nede under alle meninger", og som derfor netop ikke "kan efterprøves, men kun føles" (ibid.). Denne "nødvendighed ved det menneskelige samvær" (ibid.) er nu kendetegnet ved, at "den enkeltes frihed ikke på nogen måde forstyrres"; en sådan forstyrrelse af friheden eksisterer derimod kun i det "ikke-nødvendige menneskelige samvær, som den største del af vores liv består af" (ibid.). Kærligheden skal altså - ifølge denne utopi - netop muliggøre det, som i det normale liv ikke synes muligt: En kombination af frihed og fællesskab. Historisk set aktiverer Kafka dermed et udbredt kærlighedsideal, ifølge hvilket den individuelle selvudfoldelse skulle være mulig i intimiteten (se fx Habermas 1991, 110ff.; Werber 2003; med blik på Kafka også Schramm 2005). Og Kafka forbinder også denne længsel med spørgsmålet om anerkendelse. Hvis forlovelsen skulle have bestået, skriver han eksempelvis i tilbageblik, efter den første forlovelse med Felice Bauer er blevet brudt, ville det have forudsat, at hun havde accepteret hele hans livsform og alle hans individuelle særegenheder; hun skulle, som han skiver i november 1914, have "anerkendt det hele" (Kafka 1967, 618). Og den 1. januar 1914 skriver Kafka på tilsvarende vis, at hans idealforestilling om et ægteskab netop bestod i forhåbningen om "at kunne bestå selvstændigt inden for en enhed" (ibid., 487). Ligesom de fleste andre anerkendelsesutopier i Kafkas forfatterskab og i hans liv forbliver også denne forestilling om en altomfattende 
anerkendelse af personligheden ufuldendt. To forlovelser med Felice Bauer går i stykker, og også forholdene til Julie Wohryzeck og Milena Jesenska kan, når alt kommer til alt, ikke indfri denne forhåbning.

Med hensyn til de mest grundlæggende konflikter i forfatterskabet åbner der sig en tilgang til Kafkas værker, der peger på en søgen efter en identitet mellem frihed og fællesskab, en harmonisk tilstedeværelse af et formidlende mellemsted mellem begge poler. Dermed skriver Kafkas forfatterskab sig også ind i de store værker i den europæiske litteratur- og kulturhistorie, der igen og igen sigter efter et tredje sted mellem Vereinzelung og Vermassung - "intersubjektivitetens to modsadrettede deformationer", som Jürgen Habermas engang har udtrykt det (Habermas 1996, 63). I stedet for blot at læse Kafkas tekster - og deriblandt den tidlige kortprosatekst "Udflugten til bjergene" - som et tegn på betydningens sammenbrud og for teksternes "autorefleksivitet" (Jahraus 2006, 187), bliver det her tydeligt, hvordan Kafkas tekster også kredser om socialfilosofiske spørgsmål. Især spørgsmålet om anerkendelse, om den positive frihed og - ikke mindst - om sociale interaktioner, der kan muliggøre en overvindelse af både den 'mest skrækkelige ensomhed' og det klaustrofobiske fællesskab, som Kafkas helte ellers gang på gang er fanget i, er her centralt. Forudsætningen for et sådant utopisk mellemsted er en gensidig, reciprok form for anerkendelse, der accepterer både lighed og forskellighed som to grundtræk i menneskene. Fra Kafkas berømte kortprosatekst fra 1910 til de sene værker fra 1920erne går der med andre ord en lige linje: En kamp for anerkendelse, der hele tiden sigter efter en tilstand, hvor individets frihed og det sociale fælleskab ikke udelukker hinanden, men snarere bekræfter hinanden. Friheden, synes pointen i forfatterskabet at være, er først mulig inden for et fællesskab - et fællesskab, der samtidig nødvendigvis skal tillade den individuelle frihed. Der er altid brug for plads mellem de enkeltes "lemmer" på en udflugt - uanset hvor meget udflugtens deltagere ellers maser sig sammen og hægter sig sammen. Det første "råb" efter en overgang fra blot negativ frihed til positiv frihed var i 1910 tilsyneladende ikke succesfuldt: det var "uden klang", det vandt ingen gen-klang, ingen An-klang, kan man sige. Men Kafka og hans helte er aldrig holdt op med at stræbe efter at tilnærme sig dette ideal. En ofte forgæves stræben, men ikke desto mindre en storartet utopi.

\section{Litteratur}

Anz, Thomas (1989): Franz Kafka, München: Metzler.

Habermas, Jürgen (1991): Strukturwandel der Öffentlichkeit. Untersuchungen zu einer Kategorie der bürgerlichen Gesellschaft. Mit einem Vorwort zur Neuauflage 1990, Frankfurt am Main: Suhrkamp. Habermas, Jürgen (1996): Der philosophische Diskurs der Moderne. Zwölf Vorlesungen, Frankfurt am Main: Suhrkamp.

Honneth, Axel (2000): Das Andere der Gerechtigkeit. Aufsätze zur praktischen Philosophie, Frankfurt am Main: Suhrkamp.

Honneth, Axel (2006): Kamp om anerkendelse. Sociale konflikters moralske grammatik, København: Reitzel.

Jagow, Bettina von (2008): "Frühe Erzählungen: Der Betrachtung-Band", i Bettina von Jagow og Oliver Jahraus (red.): Kafka-Handbuch. Leben - Wirk - Wirkung, Göttingen: Vandenhoeck \& 
Ruprecht, s. 401-407.

Jahraus, Oliver (2006): Kafka. Leben, Schreiben, Machtapparate, Stuttgart: Reclam.

Kafka, Franz (1967): Briefe an Felice und andere Korrespondenz aus der Verlobungszeit, udg. af Erich Heller og Jürgen Born, New York/Frankfurt am Main: Fischer.

Kafka, Franz (1991): Processen, København: Gyldendal.

Kafka, Franz (1993): Nachgelassene Schriften und Fragmente, udg. af Hans-Gerd Koch, Michael Müller og Malcom Pasley, New York/Frankfurt am Main: Fischer.

Kafka, Franz (2008a): Fortællinger, København: Gyldendal.

Kafka, Franz (2008b): Efterladte fortællinger, København: Gyldendal.

Kobs, Jörgen (1970): Kafka. Untersuchungen zu Bewusstsein und Sprache seiner Gestalten, Bad Homburg: Athenaum.

Kurz, Gerhard (1980): Traumschrecken. Kafkas literarische Existenzanalyse, Stuttgart: Metzler.

Kurz, Gerhard (1994): "Lichtblicke in eine unendliche Verwirrung. Zu Kafkas 'Betrachtung", i Arnold, Heinz Ludwig (red.): Franz Kafka, Sonderband: Text und Kritik, München, s. 49-65.

Lehmann, Hans Thies (1984): "Der buchstäbliche Körper. Zur Selbstinszenierung der Literatur bei Franz Kafka", i Gerhard Kurz (red.): Der junge Kafka, Frankfurt am Main: Suhrkamp, s. 213-241.

Neumann Gerhard (2011): "Die Pawlatsche. Kafkas Trauma”, i Merkur. Deutsche Zeitschrift für europäisches Denken, Stuttgart, s. 848-859.

Nietzsche, Friedrich (1966): Werke in drei Bänden, udg. af Karl Schlechta, München: Hanser.

Petrarca, Francesco (1957): "Brief an Francesco Dionigi von Borgo San Sepolcro (1336)", i Karl

Heinrich Waggerl (udg.): Der Berg - Landschaft als Erlebnis, München: Kindler.

Robertson, Ritchie (1988): Kafka. Judentum, Gesellschaft, Literatur, Stuttgart: Metzler.

Schramm, Moritz (2005): "Intimitetens ambivalenser. En aktualiserende læsning af Elias Canettis Den anden proces", i Adam Paulsen (red.): Dødsfjenden. Om Elias Canettis forfatterskab, København: Politisk Revy, s. 97-123.

Schramm, Moritz (2006): "Individualitet og socialitet. Om Kafkas kamp for anerkendelse", i Moritz Schramm, Rasmus Willig et.al. (red.): Fordringen på anerkendelse, Aarhus: Klim, s. 167-185.

Schramm, Moritz (2011): “Retfærdighed har altid et særligt kendetegn...'. Retfærdighed og magt i Kafkas forfatterskab”, i Søren Fauth et al. (red.): Kafka i syv sind, Aarhus, 24 sider [in print].

Strowick, Elisabeth (2004): “Lauter Niemand'. Zur List des Namens bei Homer und Kafka”, i MLN 119, s. 564-579.

Taylor, Charles (1988): Negative Freiheit? Zur Kritik des neuzeitlichen Individualismus, Frankfurt am Main: Suhrkamp.

Werber, Niels (2003): Liebe als Roman. Zur Koeveolution intimer und literarischer Kommunikation, München: Wilhelm Fink. 